\title{
A Comparative Evaluation Of The Proximate Analysis, Mineral Contents And Phytochemical Screening Of Dioscorea Dumetorum (Bitter Yam)
}

\author{
Adebayo S. Daramola and Philip O. Amira
}

\section{ABSTRACT}

This study sought to probe into the health significance of two (white and yellow) species of Dioscorea dumetorum (bitter yam) based on their chemical composition and phytochemicals. Matured tubers were analyzed for proximate composition, mineral contents and phytochemicals, using standard analytical procedures. Significant differences $(\mathbf{p}<0.05)$ were observed between the means of some of the compositions in the two species. The results showed moisture contents of $71.45 \pm 0.15$ and $75.55 \pm 1.20 \mathrm{~g} \%$ wet weight for white and yellow species respectively. Others in $\mathrm{g} \%$ dry weight included: crude protein (white, 5.20 \pm 0.27 ; yellow, 5.70 \pm 0.35 ), crude ash (white, 4.75 \pm 0.16 ; yellow, $4.05 \pm 0.09$ ), crude fat (white, $0.70 \pm 0.20$; yellow, $0.72 \pm 0.01$ ), crude fibre (white, $15.90 \pm 0.75 ;$ yellow, 14.95 \pm 0.070 ) and carbohydrate (white, $81.86 \pm 0.17$; yellow, 75.95 \pm 0.05 ). The most predominant minerals were potassium (white, $680 \pm 0.20$; yellow, 767.85 \pm 1.35 ), phosphorus (white, $270.00 \pm 2.10$, yellow, 277.25 \pm 3.45 ), sodium (white, 70.35 \pm 1.40 ; yellow, 76.45 \pm 0.05 ) and magnesium (white, 47.10 \pm 0.25 ; yellow, 67.40 \pm 0.05$)$. The yellow species showed significantly higher concentrations over the white. The phytochemical screening revealed much presence of glycosides and alkaloids, but little presence of flavonoids, oxalates, phytates and tannins. The results justify the medicinal use of the tuber and could serve as a synergy to man and animal nutrition.

Keywords: Diascorea dumetorum, Bitter yam, Health significance, Proximate Analysis, Mineral Contents, Phytochemical Screening.

Published Online: June 11, 2020

ISSN: 2684-5199

DOI : $10.24018 /$ ejbio.2020.1.3.34

Adebayo S. Daramola *

The Federal Polytechnic, Nigeria.

(e-mail:success4daramola@ gmail.com) Philip O. Amira

The Federal Polytechnic, Nigeria.

*Corresponding Author

\section{INTRODUCTION}

Yams are the edible tubers of various species of the genus, Dioscorea and are important staple foods of many tropical countries which include Cote d'Ivoire, Ghana, Togo, Burkina Faso and Nigeria [4], [16], [21]. They serve as a major contributor to food security in West Africa [23], but, according to [15] out of the over 600 known yam species, only seven are mostly consumed. These are: Dioscorea rotundata Poir (white yam), D. cayenesis (yellow yam), D. alata (water yam), D. bulbifera (aerial yam), D. esculenta, D. praehensalis (bush yam) and D. dumentorum (bitter yam).

D. dumetorum (bitter yam in English, Esuru in Yoruba, Ona in Igbo and Kosanrogo in Hausa), identifiable by its trifoliate leaves is an important food security crop of all the yam species mostly consumed in West Africa. It is consumed primarily in Ghana, Nigeria, Cameroon, Guinea and Mali [1], and generally prepared by prolonged soaking and boiling, and has a mild bitter taste that is appealing to some but not to others and undergoes tuber hardening in the course of storage [2].

Yam is composed mainly of starch, with some proteins, lipids, vitamins and minerals [17]. In [2] it was reported that D. dumetorum is the most nutritious of the commonly consumed yam species, with fairly high protein content and a well-balanced amino acid while in [2], [6] and [11] a starch content of $75 \%$ was reported.

\section{MATERIALS AND METHODS}

The two species (white and yellow) of D. dumetorum (bitter yam) were sourced locally from Ago village in Ado Local Government Area of Ekiti State, Nigeria. All the chemicals used were from Sigma-Aldrich chemical suppliers and of analytical grade, while the water was glass distilled.

The tubers were washed, peeled, cut into small pieces and then air-dried. The air-dried pieces were milled into powder, labeled and stored in air-tight containers in the freezer prior to analysis.

Proximate composition (moisture, ash, crude fat, crude protein, and crude fibre) of samples (fresh and dry) were analyzed in triplicate using AOAC methods, (2000). The carbohydrate was estimated by difference [5].

The concentrations of some minerals in the dried samples 
were determined by digesting $2.0 \mathrm{~g}$ of each of the powdered samples using Atomic Absorption Spectrophotometeric method as outlined in [5].

\section{RESULTS AND DISCUSSION}

A. Results

TABLE I: A COMParison Of THE ProXimate Composition Of THE Two SPECIES OF DIOSCOREA DUMETORUM ANALYZED

\begin{tabular}{ccc}
\hline \hline Species & White & Yellow \\
\hline Moisture (Wet, \%) & $71.45 \pm 0.15$ & $75.55 \pm 1.20$ \\
Moisture (Dry, \%) & $6.55 \pm 0.07$ & $7.20 \pm 0.05$ \\
Crude Protein (\% & $5.20 \pm 0.27$ & $5.70 \pm 0.35$ \\
Crude Ash (\%) & $4.75 \pm 0.16$ & $4.05 \pm 0.09$ \\
Crude Fat (\%) & $0.70 \pm 0.20$ & $0.72 \pm 0.01$ \\
Crude Fibre (\%) & $15.90 \pm 0.75$ & $14.95 \pm 0.70$ \\
Carbohydrate (\%) & $81.86 \pm 0.17$ & $75.95 \pm 0.05$ \\
\hline
\end{tabular}

TABLE II: A COMPARISON OF SOME OF THE MICRO-MINERALS ANALYZED IN THE TWO SPECIES OF DIOSCOREA DUMETORUM $(\mathrm{mg} / 100 \mathrm{~g})$

\begin{tabular}{ccc}
\hline Species & White & Yellow \\
\hline Iron(Fe) & $2.55 \pm 0.20$ & $2.05 \pm 1.20$ \\
Copper(Cu) & $0.13 \pm 0.04$ & $0.07 \pm 0.01$ \\
Manganese (Mn) & $-0.01 \pm 0.00$ & $0.04 \pm 0.01$ \\
Zinc(Zn) & $0.26 \pm 0.01$ & $0.19 \pm 0.03$ \\
\hline \hline
\end{tabular}

TABLE III: A COMPARISON OF SOME OF THE MACRO-MINERALS ANALYZED IN THE TWO SPECIES OF DIOSCOREA DUMETORUM $(\mathrm{mg} / 100 \mathrm{~g})$

\begin{tabular}{ccc}
\hline Species & White & Yellow \\
\hline Potassium $(\mathrm{K})$ & $680.15 \pm 0.20$ & $767.85 \pm 2.90$ \\
Sodium(Na) & $70.35 \pm 1.40$ & $76.45 \pm 1.35$ \\
Magnesium(Mg) & $47.10 \pm 0.25$ & $67.40 \pm 0.05$ \\
Calcium(Ca) & $0.60 \pm 0.02$ & $1.65 \pm 0.01$ \\
Phosphorus $(\mathrm{P})$ & $270 \pm 2.10$ & $277 \pm 3.45$ \\
\hline \hline
\end{tabular}

TABLE IV: PHYTOCHEMICAL SCREENING OF AQUEOUS EXTRACT OF WHITE AND YELLOW SPECIES OF DIOSCOREA DUMETORUM (BITTER YAM)

\begin{tabular}{ccc}
\hline & \multicolumn{2}{c}{ Species } \\
\cline { 2 - 3 } Components & White & Yellow \\
\hline Alkaloids & +++ & +++ \\
Glycosides & +++ & +++ \\
Flavonoids & + & + \\
Oxalates & + & + \\
Tannin & + & + \\
Saponins & + & + \\
\hline \hline
\end{tabular}

\section{B. Discussion}

\section{B 1. Proximate composition}

The comparison of the average proximate composition of the investigated species (yellow and white) is as presented in Table I. In both species, carbohydrate has the highest values followed by the moisture (wet weight) while fat has the least. The values for moisture recorded in this study ranged between 71 and $75 \%$ which is slightly lower than the value $(70.04 \%)$ by [19]. The high moisture content of the fresh tuber is a pointer to the fact that the tuber cannot be stored for a long period of time after harvest by [19]. The moisture levels of the dry sample were within the acceptable limit of not more than $10 \%$ for long term storage of flour [21].

According to [21], tubers have never been known as sources of lipids, however, the values for both species got in this study were comparable to the value $(0.75 \%)$ got by [19] but higher than $0.1 \%$ reported in [9] for more common yam tubers.

The protein contents reported for the two species were twice higher than the $2.5 \%$ reported for D. dumetorum in [9] but almost in agreement with the value reported in [19] and [21]. According to [19], the variation may be attributed to factors such as age of plant, season of growth, time of harvest, soil nutrient composition and research methodology. However, the species are richer in crude protein than other varieties [12]. Yams are low in protein, though, [12], the higher values got for $D$. dumetorum could be made use of in malnourished communities [19].

The values for the crude fibre in the two species were greatly higher than $2.10-3.47 \%$ reported in [21]. Crude fibre increases stool bulk and moves the waste faster in the gastrointestinal tract, which helps in the prevention of digestive tract problems such as diverticulosis and constipation, aside other health benefits which include; decreasing rate of sugar uptake, decreasing blood cholesterol and binding carcinogens [10], [21].

The ash contents of the two species did not show any significant difference from each other. However, the values were significantly lower than the values $(7.79 \%)$ reported in [21] and slightly higher than $3.45 \%$ reported in [19]. The values were comparable to literature values as reported in [2], [7] and [22]. When compared to the values reported in [21], the carbohydrate value for the white specie was a bit lower while the yellow specie showed higher value. Nevertheless, the values could make them reliable food security crops.

\section{B 2. Mineral composition}

Mineral analysis as presented in Tables II and III showed that the level of potassium was the highest, agreeing with the findings in [9] and [19] where also reported potassium levels as the highest amongst the minerals analyzed. According to [14], potassium plays a vital role in body cells by assisting in muscle contraction as well as in the maintenance of fluid and electrolyte balance. Next in concentration was phosphorus followed by sodium and magnesium. This trend was in agreement with the findings in [21]. However, the value obtained for calcium was greatly lower than the value reported in [21].

The concentrations of micro-minerals, such as iron, and copper compared well with reported values by [3] and [21] while the values for manganese and zinc were greatly lower. According to [14], the mineral content of the yam depends on the mineral content of the soil in which the tubers grow, time of planting and harvesting as well as the amount of water available in the soil.

\section{B 3. Phytochemical screening}

The results of phytochemical screening are presented in Table IV. Alkaloids and glycosides were highly present while tannins, phytates, oxalates and flavonoids showed little presence. The presence of these compounds lends credence to their pharmacological effects [19]. According to [19], some alkaloids are among the most potent known poisons; hence the presence of alkaloids in this study explains the use of D. dumetorum as an arrow poison. In [20] reported the presence of hypoglycaemic alkaloids in a number of plants, this corroborates the use of $D$. dumetorum in the treatment of 
diabetic patients. The presence of flavonoids was found in this study. In [13] reported the hypoglycaemic efficacy of some flavonoids,

Saponins have been reported to have hypocholesterolaemic effect, aside other pharmacological activities [19], while tannins form complexes with protein and reduce their digestibility and palatability [11]. However, according to [18], the contents of tannins are known to reduce through cooking. Phytates and oxalates are known to adversely affect mineral bioavailability [8].

\section{CONCLUSION}

This study has shown that D. dumetorum (bitter yam) contains crude fibre and minerals such as potassium, phosphorus, sodium and magnesium; with the yellow species having higher percentages of the minerals over the white species. The protein levels in the two species are low, thus, the tuber should be eaten with high-protein sauce for good nutritive value. The study also revealed high presence of phytochemicals like alkaloids and glycosides, which may be attributed to its pharmacological potentials. The minimal presence of phytates, oxalates, saponins and tannins could guarantee its safe recommendation for food processing applications.

\section{REFERENCES}

[1] Adedayo, B.C., Oboh, G. \& Akindahunsi, A.A. (2013). Effect of cooking on the antioxidant properties of two varieties of bitter yam (Dioscorea dumetorum). Journal of Sustainable Technology, 4 (2): 104-113.

[2] Afoakwa, E.O. \& Sefa-Dedeh, S. (2001). Chemical composition and quality changes occurring in Dioscorea dumetorum pax tubers after harvest. Food Chemistry, 77: 85-91.

[3] Agbor-Egbe, I.J. \& Treche, S. (1995). Evaluation of the chemica composition of Camerounian Yam Germsplasm. Journal of Food Composition and Analysis, 8: 274-283.

[4] Amanze, N.J., Agbo, N.J., Eke-Okoro, O.N. \& Njoku, D.N. (2011) Selection of yam seeds from open pollination for adoption in yam (Dioscorea rotundata Poir) production zones in Nigeria. Journal of Plant Breeding and Crop Science, 3(4): 68-73.

[5] AOAC (1990). Methods of the Association of Official Analysis Chemists. Official methods of Analysis (15th Ed.). Virginia Assoc. of Anal. Chem., U.S.A.,pg.1141.

[6] Bell, A. \& Favier, J.C. (1981). Effect of traditional food processing methods on the nutritional value of yam in Cameroon. IDRC: tropica root crops: Proc. I Trienn Root Crops Symp., Ibadan. 163: 214-224.

[7] Bhandari, M.R., Kasai, T. \& Kawabata, J.(2003). Nutritiona evaluation of wild edible yam (Dioscorea sp.) tubers of Nepal. Food Chemistry, 82(4): 619-623

[8] Bhandari, M.J \& Kawabata, J. (2006). Cooking effects on oxalate, phytate, trypsin and $\alpha$-amylase inhibitors of wild yam tubers of Nepal. Journal of Food Composition and Analysis, 19: 524-530.

[9] Bradbury, J.H. \& Holloway, W.D. (1988). Chemistry of tropical roo crops. Significance for Nutrition and Agriculture in the Pacifics. ACTAR. Monograph No.6. pp.201.

[10] Chaney, S.G. (2006). Principles of Nutrition I: Macronutrients Textbook of Biochemistry with Clinical Correlations. Devlin, T.M.(ed.). wiley-liss, Hoboken, N.J. pp1080-1082.

[11] Eka, O.U. (1985). The chemical composition of yam tubers. In: Advances in yam research. The Biochemistry and Technology of yam tubers. Osuji, G. (ed.). Biochemical Society of Nigeria, Enugu, Nigeria. 1: $51-75$.

[12] Eka, O.U. (1998). Roots and Tubers. In: Nutrition Quality of Plant Foods, Post-Harvest Research Unit, University of Benin, Benin City, Nigeria. p.14.

[13] Evans, W.C. (1999). "Trease and Evans" Pharmacognosy, 14th ed., W.B. Saunders Company Ltd., London. Pp. 376-635.
[14] Frossard, E. (2000). Potential for increasing the content and bioavailability of $\mathrm{Fe}, \mathrm{Zn}$ and $\mathrm{Ca}$ in plants for human nutrition. J. Sci. Food Agric., 80: 861-879.

[15] Jayakody, L., Hoover, R., Liu, Q. \& Donner, E.(2007). Studies on tuber starches. II. molecular structure, composition and physicochemical properties of yam (Dioscorea sp.) starches grown in Sri Lanka. Carbohydrate Polymers, 69: 148-163

[16] Kouakou, M.D., Dabonne, S., Guehi, T. \& Kuoame, L.P. (2010) Effects of post-harvest storage on some biochemical parameters of different parts of two yams species (Dioscorea spp.). African Journal of Food Science and Technology, 1: 1-19.

[17] Lasztity, R., Hidvegi, M. \& Bata, A.(1998). Saponins in food. Food Reviews International, 14 (4): 371-390.

[18] Lewu, M.N., Adebbola, P.O. \& Afolayan, A.J. (2010). Effect of cooking on the mineral contents and anti-nutritional factors in seven accessions of Colocasia esculenta (L) Schott growing in South Africa Journal of Food Composition and Analysis, 23: 389-393.

[19] Nimenibo-Uadia, R.I. \& Oriakhi, A.V. (2017). Proximate, Mineral and Phytochemical composition of Dioscorea dumetorum Pax. J. Appl. Sci. Environ. Manage., 21 (4): 771-774.

[20] Oliver-Bever, B. (1980). Oral hypoglycaemic plants in West Africa Journal of Ethnopharm., 2: 119-127.

[21] Polycarp, D., Afoakwa, E.O., Budu, A.S. \& Otoo, E. (2012) Characterization of chemical composition and anti-nutritional factors in seven species within the Ghananian yam (Diascorea) germplasm International Food Res. J., 19(3): 985-992.

[22] Shanthakumari, S., Mohan, V.R. \& J. De Britto, A. (2008). Nutritional evaluation and elimination of toxic principles in wild yam (Dioscorea spp.). Tropical and Subtropical Agroecosystems, 8: 313-319.

[23] Zannou, A. (2006). Socio-economic, agronomic and molecular analysis of yam and cowpea diversity in the Guinea-Sudan transition zone of Benin. PhD thesis, Wageningen University. 